\title{
Synthesis, Characterization, Chemical Nuclease Activity and Antimicrobial Evaluation of Tridentate (NOS Donor) Schiff Base Ligand: 2-(4-(Thiophen-2- yl)but-3-en-2-ylideneamino)phenol and their Metal- Organic Hybrids
}

\author{
G. R. PRIYA DHARSINI, T. CLARINA and V. RAMA*
}

Department of Chemistry, Sarah Tucker College, Manonmaniam Sundarnar University, Abishekapatti, Tirunelveli - 627 012, Tamilnadu, India

rama242002@gmail.com

Received 28 June 2017 / Accepted 20 July 2017

\begin{abstract}
Cu}(\mathrm{II}), \mathrm{Co}(\mathrm{II}), \mathrm{Ni}(\mathrm{II})$ and $\mathrm{Zn}$ (II) metal-organic hybrids of new tridentate (NOS donor) Schiff base ligand derived from 4-(thiophen-2-yl)but-3-en-2-one (TB) and 2-aminophenol (AP) were synthesized, characterized and their pharmacological activities were evaluated. Possible geometry of the hybrid derivatives and the chelating atoms were investigated on the source of elemental analysis, magnetic moment, molar conductivity, infrared, EPR, NMR, electronic and mass spectral studies. The results were consistent with a three coordination environment around the metal ion. Synthesized compounds were screened for in vitro antimicrobial activity against bacteria Escherichia coli, Pseudomonas aeruginosa, Klebsiella pneumonia, Staphylococcus aureus, Staphylococcus saprophyticus and fungi Candida albicans. Hybrid derivatives showed improved antibacterial and antifungal activity compared with the ligand 2(-4-(thiophen-2-yl)but-3-en-2-ylidene amino)phenol (TBAP). DNA cleavage experiments done by means of gel electrophoresis with corresponding hybrid derivatives in the presence of $\mathrm{H}_{2} \mathrm{O}_{2}$ showed pronounced discernible DNA cleavage.
\end{abstract}

Keywords: Antimicrobial, DNA cleavage, Schiff base, Tridentate, Thiophene

\section{Introduction}

Schiff base ligands containing N, O, S donor atoms show broad biological activity and are of particular interest because of the array of ways in which they are bonded to metal ions ${ }^{1}$. Thiophene and its derivatives are essential heterocyclic compounds. They possess wide variety of biological activities such as antimicrobial, diabetes mellitus ${ }^{2}$, cholesterol inhibition activity $^{3}$, antitumor and antiallergic activities ${ }^{4}$. On the other hand, 2-aminophenol based Schiff bases have been the subject of extensive exploration because of their wide application. Also hybrid derivatives of Schiff bases with heterocyclic system find applications 
as potential drugs ${ }^{5}$. Resistance of pathogenic bacteria towards existing antibiotics is swiftly becoming a foremost world-wide problem. Thus invent of new compounds to deal with resistant bacteria has become one of the vital area of antibacterial research today. Although many Schiff bases and their metal complexes had been extensively studied, a perusal of literature revealed that no Schiff base of 2(-4-(thiophen-2-yl)but-3-en-2-ylidene amino)phenol and their hybrid derivatives had been reported. Thus there is a great necessitate to explore their potential and the present study is one in this direction. Motivated by the above observations in the present work we had reported the synthetic as well as characterisation particulars and biological activities (antimicrobial and DNA cleavage activity) of the Schiff base ligand TBAP by the condensation of 4-(thiophen-2-yl)but-3-en-2-one with 2-aminophenol and their metal(II) hybrid derivatives of $\mathrm{Cu}(\mathrm{II}), \mathrm{Co}(\mathrm{II}), \mathrm{Ni}(\mathrm{II})$ and $\mathrm{Zn}(\mathrm{II})$.

\section{Experimental}

All solvents and chemicals used were of analytical reagent grade from Merck and Sigma Aldrich. Melting point of all synthesized compounds was determined using open capillary tube and was reported uncorrected. UV spectra were recorded on Systronic pc based double beam spectrophotometer 2202. IR spectra were recorded by making $\mathrm{KBr}$ pellets on Shimadzu Fourier transform IR spectrophotometer, FT/IR-8400S. ${ }^{1} \mathrm{H}$ and ${ }^{13} \mathrm{C}$ NMR spectra were recorded on a Bruker $400 \mathrm{MHz}$ spectrometer in DMSO-d6 solvent. C, H, N and $\mathrm{S}$ data were obtained by using Elementar Vario EL III. Molar conductance was measured on the ELICO (CM-185) conductivity bridge using $10^{-3} \mathrm{M}$ solution in DMSO by dip-type conductivity cell fitted with a platinum electrode. Magnetic susceptibility of complexes was measured by Gouy's method using copper sulphate as calibrant. Thermogram was analysed and recorded using NETZSCH STA 449F3 TG/DTA instrument in the temperature range from $30{ }^{\circ} \mathrm{C}$ to $900{ }^{\circ} \mathrm{C}$ under nitrogen atmosphere. The mass spectral analysis was carried out using JEOL D-300 (EI) mass spectrometer. EPR measurement of the copper complex of TBAP was recorded at liquid nitrogen temperature using a JEOL Model JES FA200 instrument. Gel electrophoresis experiment was done with CT DNA, with hydrogen peroxide as oxidant. Pharmacological activity of the synthesized compounds against selected bacteria and fungi species was tested using Kirby-Bauer disc diffusion method.

\section{Synthesis of ligand: 2(-4-(Thiophen-2-yl)but-3-en-2-ylideneamino)phenol (TBAP)}

To an ethanolic solution of acetone $(5 \mathrm{mmol})$, sodium hydroxide solution $(5 \mathrm{mmol})$ was added gradually with even stirring. To the above mixture ethanolic solution of 2-thiophenecarboxaldehyde $(5 \mathrm{mmol})$ was added drop wise and stirred for 2-3 hours. Then ethanolic solution of 2-aminophenol ( $5 \mathrm{mmol}$ ) was added drop by drop and refluxed for 5-6 hours. After completion of the reaction (monitored by TLC) the yellow precipitate obtained was filtered, washed with ethanol, dried and recrystallized from ethanol yield 89\%. Reaction sequence for the synthesis of TBAP is shown in Scheme 1.

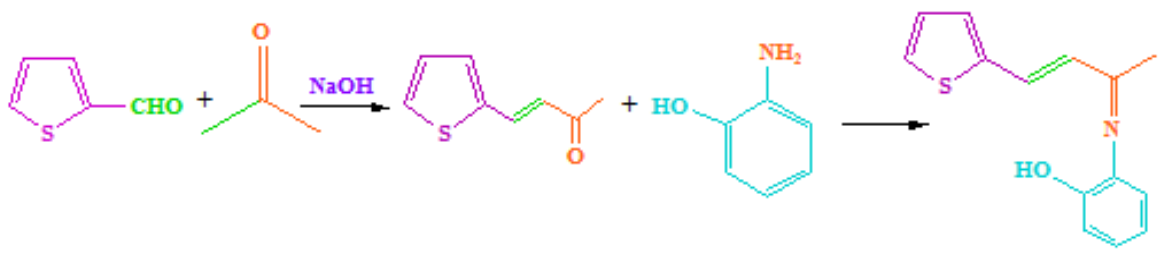

Scheme 1. Synthesis of Schiff base ligand: (TBAP) 


\section{Synthesis of metal complexes}

Hot ethanolic solutions of TBAP $(2 \mathrm{mmol})$ and respective hydrated metal(II) chlorides (viz., $\mathrm{Cu}, \mathrm{Co}, \mathrm{Ni}$ and $\mathrm{Zn}$ ) $(2 \mathrm{mmol})$ were mixed in the ratio 1:1 under constant stirring and refluxed for 5-6 hours. Coloured precipitates of hybrid derivatives obtained in each case was filtered, washed with ethanol followed by diethylether and dried in vacuum over fused $\mathrm{CaCl}_{2}$.

\section{CT DNA cleavage study}

Cleavage of CT DNA was examined by means of agarose gel electrophoresis. The gelelectrophoresis experiment was performed by incubation of the samples containing $50 \mu \mathrm{M}$ of each synthesized compound, $30 \mu \mathrm{M}$ CT DNA and $40 \mu \mathrm{M}$ hydrogen peroxide $\left(\mathrm{H}_{2} \mathrm{O}_{2}\right)$ for $2 \mathrm{~h}$ at $37{ }^{\circ} \mathrm{C}$ in Tris- $\mathrm{HCl} / \mathrm{NaCl}$ buffer $(\mathrm{pH} \mathrm{7.2)}$. The samples were electrophoresis after incubation at $50 \mathrm{~V}$ for $2 \mathrm{~h}$ on $1 \%$ agarose gel using Tris-acetic acid-EDTA buffer, (pH 8.0). The gel was then stained using $1 \mu \mathrm{g} \mathrm{cm}^{-3}$ ethidium bromide (EB) and photographed under ultraviolet light.

\section{Antimicrobial activity}

In vitro antimicrobial activity of synthesized compounds was investigated using Kirby-Bauer disc diffusion method ${ }^{6}$. From the many media available, the current NCCLS: national committee for clinical laboratory standards guidelines has recommend using Sabouraud dextrose agar medium for Candida and Mueller-Hinton agar medium for bacteria. The antibacterial and antifungal activity was done at $1 \mathrm{mg} / \mathrm{mL}$ concentration of the synthesized compounds in DMSO solvent. Plates inoculated with bacteria and fungi was incubated at $35-37{ }^{\circ} \mathrm{C}$ for $24-48 \mathrm{~h}$ and at $30{ }^{\circ} \mathrm{C}$ for $24-48 \mathrm{~h}$ respectively and then the diameter of the inhibition zone was measured in millimetres. Standard discs of ciprofloxacin (antibacterial agent) and nystatin (antifungal agent) served as positive control. Blank paper disks were impregnated with $10 \mu \mathrm{L}$ of the stock solutions. When filter paper disc impregnated with tested chemical is placed on agar, the chemical would diffuse from the disc into the agar and place the chemical in the agar around the disc. The area of chemical infiltration around the disc will be determined by the solubility and molecular size of the chemical. When an organism is positioned on the agar it will not grow in the area around the disc if it is susceptible to the chemical. This area of no growth around the disc is called "Zone of inhibition".

\section{Characterization data}

\section{2(-4-(Thiophen-2-yl)but-3-en-2-ylideneamino)phenol (TBAP)}

Yellow. Yield: $89 \%$. M.p.: $103{ }^{\circ} \mathrm{C}$. Anal. Calc. $\left(\mathrm{C}_{14} \mathrm{H}_{13} \mathrm{NOS}\right)$. M.wt: 243.32. Elem. Anal. Calc: C, 69.11; H, 5.39; N, 5.76, S, 13.18; found: C, 68.97; H, 5.42; N, 5.64, S, 13.02; \% EIMS: $(\mathrm{m} / \mathrm{z}) 243(\mathrm{RI} 17 \%),(\mathrm{m} / \mathrm{z}) 228$ (RI 100\%), (m/z) $109(\mathrm{RI} 16 \%),(\mathrm{m} / \mathrm{z}) 84(\mathrm{RI} 11 \%)$, $(\mathrm{m} / \mathrm{z}) 58(\mathrm{RI} 4 \%)$; UV/Vis $\lambda_{\max }(\mathrm{nm}): 256,372 . \mathrm{IR} v_{\max }\left(\mathrm{cm}^{-1}\right): 3203(\mathrm{OH}), 1696(\mathrm{C}=\mathrm{N}), 1606$ (olefinic $\mathrm{C}=\mathrm{C}), 1366\left(\mathrm{CH}_{3}\right), 1251(\mathrm{C}-\mathrm{O}), 766\left(\mathrm{C}-\mathrm{S}\right.$ (thiophene)). ${ }^{1} \mathrm{H}$ NMR (DMSO-d6 ppm): $2.03\left(\mathrm{~s}, 3 \mathrm{H}, \mathrm{CH}_{3}\right), 6.58,6.92(\mathrm{~d}, 1 \mathrm{H}, \mathrm{CH}=\mathrm{CH}), 6.72-7.89(\mathrm{~m}$, aromatic-H), $11.71(\mathrm{~s}, 1 \mathrm{H}$, $\mathrm{OH}) .{ }^{13} \mathrm{C}$ NMR (DMSO-d6 ppm): 156.27 (carbonyl), 162.34 (azomethine), 136.21, 147.68 (olefinic $\mathrm{C}=\mathrm{C}$ ), 115-140 (aromatic), $24.27\left(\mathrm{CH}_{3}\right)$.

Copper complex of 2(-4-(thiophen-2-yl)but-3-en-2-ylideneamino)phenol (CuTBAP)

Dark green, Yield: $87 \%$. M.p.: $128{ }^{\circ} \mathrm{C}$. Anal. Calc. $\left(\mathrm{C}_{14} \mathrm{H}_{14} \mathrm{CuNO}_{2} \mathrm{~S}\right)$. M.wt: 323.88. Elem. Anal. Calc: C, 51.92; H, 4.36; N, 4.32; Cu, 19.62; S, 9.90; found: C, 51.96; H, 4.25; N, 4.21; $\mathrm{S}, 9.74 ; \mathrm{Cu}, 19.51 ;$ Molar conductance $\Lambda \mathrm{m}\left(\Omega^{-1} \mathrm{~cm}^{2} \mathrm{~mol}^{-1}\right): 84.92 ; \mu_{\text {eff }}($ magnetic moment 
(BM): 1.92; UV/Vis $\lambda_{\max }(\mathrm{nm}): 241,353,574 . \mathrm{IR} v_{\max }\left(\mathrm{cm}^{-1}\right): 3439$ (coordinated water), $1677(\mathrm{C}=\mathrm{N}), 1603$ (olefinic $\mathrm{C}=\mathrm{C}), 1366\left(\mathrm{CH}_{3}\right), 1223$ (C-O), 778 (C-S (thiophene)), 577 (M-O), 463 (M-N). ${ }^{1} \mathrm{H}$ NMR (DMSO-d6 ppm): 2.07 (s, 3H, $\mathrm{CH}_{3}$ ), 6.63, 6.89 (d, 1H, CH= $\mathrm{CH}), 6.83-7.63$ (m, aromatic-H), 4.16 (br, $\left.2 \mathrm{H}, \mathrm{H}_{2} \mathrm{O}\right)$. TGA wt. Loss: \% found/calc. (temp.): $5.53 / 5.56\left(155-215^{\circ} \mathrm{C}\right) ; 38.13 / 38.12\left(215-420{ }^{\circ} \mathrm{C}\right) ; 35.64 / 35.67\left(420-615^{\circ} \mathrm{C}\right)$.

\section{Cobalt complex of 2(-4-(thiophen-2-yl)but-3-en-2-ylideneamino)phenol (CoTBAP)}

Reddish brown, Yield: $84 \%$. m.p.: $149{ }^{\circ} \mathrm{C}$. Anal. calc. $\left(\mathrm{C}_{14} \mathrm{H}_{14} \mathrm{Cl}_{2} \mathrm{CoNO}_{2} \mathrm{~S}\right)$. M.wt: 390.17 . Elem. Anal. Calc: C, 43.10; H, 3.62; N, 3.59; Co, 15.10; S, 8.22; found: C, 43.15; H, 3.58; $\mathrm{N}, 3.63 ; \mathrm{S}, 8.17$; Co, 14.98; Molar conductance $\Lambda \mathrm{m}\left(\Omega^{-1} \mathrm{~cm}^{2} \mathrm{~mol}^{-1}\right): 4.75 ; \mu_{\text {eff }}$ (magnetic moment $(\mathrm{BM})): 4.87$; UV/Vis $\lambda_{\max }(\mathrm{nm}): 247,364,427,614,741$. IR $v_{\max }\left(\mathrm{cm}^{-1}\right): 3419$ (coordinated water), $1680(\mathrm{C}=\mathrm{N}), 1609$ (olefinic $\mathrm{C}=\mathrm{C}), 1366\left(\mathrm{CH}_{3}\right), 1227(\mathrm{C}-\mathrm{O}), 736(\mathrm{C}-\mathrm{S}$ (thiophene)), 568 (M-O), 468 (M-N), 418 (M-Cl). ${ }^{1} \mathrm{H}$ NMR (DMSO-d6 ppm): 2.08 (s, 3H, $\left.\mathrm{CH}_{3}\right), 6.77,6.99(\mathrm{~d}, 1 \mathrm{H}, \mathrm{CH}=\mathrm{CH}), 6.86-7.71\left(\mathrm{~m}\right.$, aromatic-H), $4.13\left(\mathrm{br}, 2 \mathrm{H}, \mathrm{H}_{2} \mathrm{O}\right)$. TGA wt. Loss: \% found/calc. (temp.): $4.59 / 4.61\left(150-210^{\circ} \mathrm{C}\right) ; 18.18 / 18.20\left(210-365^{\circ} \mathrm{C}\right) ; 36.66 / 36.65$ $\left(365-560{ }^{\circ} \mathrm{C}\right) ; 21.25 / 21.28\left(560-725^{\circ} \mathrm{C}\right)$.

\section{Nickel complex of 2(-4-(thiophen-2-yl)but-3-en-2-ylideneamino)phenol (NiTBAP)}

Grassy green, Yield: 86\%. m.p.: $144{ }^{\circ} \mathrm{C}$. Anal. calc. $\left(\mathrm{C}_{14} \mathrm{H}_{14} \mathrm{Cl}_{2} \mathrm{NiNO}_{2} \mathrm{~S}\right)$. M.wt: 389.93 . Elem. Anal. Calc: C, 43.12; H, 3.62; N, 3.59; Ni, 15.05; S, 8.22; found: C, 43.04; H, 3.64; $\mathrm{N}, 3.51 ; \mathrm{S}, 8.14 ; \mathrm{Ni}, 14.94 ;$ Molar conductance $\Lambda \mathrm{m}\left(\Omega^{-1} \mathrm{~cm}^{2} \mathrm{~mol}^{-1}\right): 5.12 ; \mu_{\text {eff }}$ (magnetic moment $(\mathrm{BM})): 2.97$; UV/Vis $\lambda_{\max }(\mathrm{nm}): 251,340,410,602,727$. IR $v_{\max }\left(\mathrm{cm}^{-1}\right): 3350$ (coordinated water), $1681(\mathrm{C}=\mathrm{N}), 1608$ (olefinic $\mathrm{C}=\mathrm{C}), 1365\left(\mathrm{CH}_{3}\right), 1229(\mathrm{C}-\mathrm{O}), 739(\mathrm{C}-\mathrm{S}$ (thiophene)), 568 (M-O), 465 (M-N), 419 (M-Cl). ${ }^{1} \mathrm{H}$ NMR (DMSO-d6 ppm): 2.09 (s, 3H, $\left.\mathrm{CH}_{3}\right), 6.63,6.88(\mathrm{~d}, 1 \mathrm{H}, \mathrm{CH}=\mathrm{CH}), 6.74-7.63\left(\mathrm{~m}\right.$, aromatic-H), $4.19\left(\mathrm{br}, 2 \mathrm{H}, \mathrm{H}_{2} \mathrm{O}\right)$.

\section{Zinc complex of 2(-4-(thiophen-2-yl)but-3-en-2-ylideneamino)phenol (ZnTBAP)}

Dirty white, Yield: $84 \%$. m.p.: $136{ }^{\circ} \mathrm{C}$. Anal. calc. $\left(\mathrm{C}_{14} \mathrm{H}_{14} \mathrm{ZnNO}_{2} \mathrm{~S}\right)$. M.wt: 325.72. Elem. Anal. Calc: C, 51.62; H, 4.33; N, 4.30; Zn, 20.08; S, 9.84; found: C, 51.53; H, 4.26; N, 4.27; S, 9.80; Zn, 19.93; Molar conductance $\Lambda \mathrm{m}\left(\Omega^{-1} \mathrm{~cm}^{2} \mathrm{~mol}^{-1}\right): 98.42 ; \mathrm{IR} v_{\max }\left(\mathrm{cm}^{-1}\right): 3303$ (coordinated water), $1680(\mathrm{C}=\mathrm{N}), 1601$ (olefinic $\mathrm{C}=\mathrm{C}), 1363\left(\mathrm{CH}_{3}\right), 1226(\mathrm{C}-\mathrm{O}), 787(\mathrm{C}-\mathrm{S}$ (thiophene)), 579 (M-O), 468 (M-N). ${ }^{1} \mathrm{H}$ NMR (DMSO-d6 ppm): 2.07 (s, 3H, $\mathrm{CH}_{3}$ ), 6.64, $6.95(\mathrm{~d}, 1 \mathrm{H}, \mathrm{CH}=\mathrm{CH}), 6.86-7.7\left(\mathrm{~m}\right.$, aromatic-H), $4.16\left(\mathrm{br}, 2 \mathrm{H}, \mathrm{H}_{2} \mathrm{O}\right)$.

\section{Results and Discussion}

The structure of complexes was confirmed by their physiochemical analysis such as elemental and conductivity measurement. Precise information about their structure is obtained from IR, NMR and EPR spectral measurements. The complexes formulated from the analytical data and molar conductance data supported the suggested formulae $\left[\mathrm{MLH}_{2} \mathrm{O}\right]$ where $\mathrm{M}=\mathrm{Cu}(\mathrm{II}), \mathrm{Zn}(\mathrm{II})$ and $\left[\mathrm{MLH}_{2} \mathrm{OCl}_{2}\right]$ where $\mathrm{M}=\mathrm{Co}(\mathrm{II}), \mathrm{Ni}(\mathrm{II})$ and $\mathrm{L}=\left(\mathrm{C}_{14} \mathrm{H}_{13} \mathrm{NOS}\right)$. The complexes were highly coloured, insoluble in water as well as in common organic solvents but soluble in highly coordinating solvents such as DMSO and DMF. Synthesized compounds were non hygroscopic, highly stable under normal conditions.

\section{Molar conductance}

The molar conductance of $10^{-3} \mathrm{M}$ solutions of the complexes in DMSO was carried out at room temperature. CuTBAP and ZnTBAP showed values, 84.92, $98.42 \mathrm{~S} \mathrm{~cm}^{2} \mathrm{~mol}^{-1}$ respectively, which indicated the electrolytic nature of the above complexes. This was further 
confirmed by the positive silver nitrate test which lead to the formation of white precipitate. On the other hand CoTBAP and NiTBAP showed the values 4.75 and $5.12 \mathrm{~S} \mathrm{~cm}^{2} \mathrm{~mol}^{-1}$ respectively. The obtained values were taken as good indication for the existence of a nonelectrolyte nature ${ }^{7}$ of the CoTBAP and NiTBAP complexes.

\section{Mass spectra}

Mass spectra of the ligand TBAP showed a molecular ion peak at $m / z 243$ (RI 17\%), which coincide with molecular weight of TBAP corresponding to $\left[\mathrm{C}_{14} \mathrm{H}_{13} \mathrm{NOS}\right]^{+}$ion. The spectrum also showed fragments at $m / z 228$ (RI 100\%), 109 (RI 16\%), 84 (RI 11\%) and 58 (RI 4\%) corresponding to $\left[\mathrm{C}_{13} \mathrm{H}_{10} \mathrm{NOS}\right]^{+},\left[\mathrm{C}_{6} \mathrm{H}_{5} \mathrm{~S}\right]^{+}$and $\left[\mathrm{C}_{4} \mathrm{H}_{3} \mathrm{~S}\right]^{+}$respectively. This data was in good agreement with the proposed molecular formula of the ligand TBAP.

\section{Infrared spectra}

IR spectra of TBAP and its metal organic hybrids were carried out in the range of $4000-400 \mathrm{~cm}^{-1}$. In TBAP appearance of an intense band at $1696 \mathrm{~cm}^{-1}$ was attributed to the formation of $\mathrm{C}=\mathrm{N}$ (azomethine). In hybrid derivatives this band was found to be shifted. This suggested the coordination of azomethine nitrogen to metal atom in complexation ${ }^{8}$ due to the donation of electron density from nitrogen to metal.

FT-IR of the ligand showed a broad band around $3200 \mathrm{~cm}^{-1}$ due to $\mathrm{OH}$ stretching frequency of phenolic group. Disappearance of this band in all the hybrid derivatives indicated deprotonation of the phenolic $\mathrm{OH}$ and involvement of the oxygen atom in bonding. Presence of coordinated water molecules in the metal organic hybrids was indicated by a band around $3502-3303 \mathrm{~cm}^{-1}$ and also by the bands in the range $850-873 \mathrm{~cm}^{-1}$ which indicated binding of water molecules to the metal ions ${ }^{9}$. Phenolic C-O stretching frequency ${ }^{10}$ of TBAP was observed at $1251 \mathrm{~cm}^{-1}$. Upon chelation this band was shifted to lower frequency (1223-1229) $\mathrm{cm}^{-1}$ which indicated the participation of the oxygen atom of phenolic group in coordination to the metal ion. This was further supported by the formation of new bands of medium intensity at $568-579 \mathrm{~cm}^{-1}$ assigned to (M-O) vibration ${ }^{11}$. The band at $766 \mathrm{~cm}^{-1}$ in TBAP due to $v(\mathrm{C}-\mathrm{S})$ stretching of thiophene was shifted in the hybrid derivatives (736-787) $\mathrm{cm}^{-1}$, which suggested coordination of sulphur atom with the metal ion $^{12}$. Appearance of band in the region $1606 \mathrm{~cm}^{-1}$ and in the region 1601-1609 $\mathrm{cm}^{-1}$ was attributed to $\mathrm{C}=\mathrm{C}$ stretching frequency in TBAP and its complexes respectively. A band at $1366 \mathrm{~cm}^{-1}$ in the ligand was due $\left(\mathrm{CH}_{3}\right)$ stretching frequency. Upon complexation this band remained unaffected ${ }^{13}$. Further the formation of medium intensity non-ligand bands around 463-468 $\mathrm{cm}^{-1}$ and $418-419 \mathrm{~cm}^{-1}$ provided compelling evidence for the formation of (M-N) and $(\mathrm{M}-\mathrm{Cl})$ bond $^{11}$. From the IR data it was apparent that the ligand TBAP was coordinated to the metal ions via azomethine-N, thiophene-S and phenolic-OH. Other coordination sites in the complexes were satisfied by chloride ions.

\section{${ }^{1} \mathrm{H}$ and ${ }^{13} \mathrm{C}$ NMR spectra}

${ }^{1} \mathrm{H}$ NMR spectra of TBAP in DMSO-d6 and its metal organic hybrids showed the following signals. Ligand (TBAP): $2.03 \mathrm{ppm}\left(\mathrm{s}, 3 \mathrm{H}, \mathrm{CH}_{3}\right), 6.58 \mathrm{ppm}, 6.92 \mathrm{ppm}(\mathrm{d}, 1 \mathrm{H}, \mathrm{CH}=\mathrm{CH})$, 6.72-7.89 ppm (m, aromatic-H), $11.71 \mathrm{ppm}(\mathrm{s}, 1 \mathrm{H}, \mathrm{OH})^{14}$.

Hybrid derivatives of TBAP: 2.07-2.09 ppm (s, 3H, $\left.\mathrm{CH}_{3}\right), 6.63-6.77 \mathrm{ppm}$ and 6.88-6.99 ppm $(\mathrm{d}, 1 \mathrm{H}, \mathrm{CH}=\mathrm{CH}), 6.74-7.71 \mathrm{ppm}(\mathrm{m}$, aromatic-H). Involvement of phenolic hydrogen $(\mathrm{OH})$ in chelation through the deprotonation of $\mathrm{OH}$ was indicated by the disappearance of the $\mathrm{OH}$ signal in the ${ }^{1} \mathrm{H}$ NMR spectrum of the hybrid derivatives. Signal around 4.13-4.19 ppm with integration analogous to two protons was assigned to coordinated water molecule in the hybrid derivatives ${ }^{15}$. 
${ }^{13} \mathrm{C}$ Nuclear magnetic resonance spectra of TBAP showed signal at $156.27 \mathrm{ppm}$ due to carbonyl carbon, signal at $162.34 \mathrm{ppm}$ due to azomethine carbon, signal at $115-140 \mathrm{ppm}$ due to aromatic carbon and signal at $24.27 \mathrm{ppm}$ due to $\mathrm{CH}_{3}$ carbon, signal at 147.68 and 136.21 ppm due to $\mathrm{CH}=\mathrm{CH}$ carbons.

\section{Electronic spectra and magnetic moment measurements}

UV-Vis spectra of TBAP and its hybrid derivatives (Figure 1a) were recorded at room temperature using DMSO as solvent. Electronic spectra of TBAP showed absorptions at $256 \mathrm{~nm}$ and $372 \mathrm{~nm}$ which were attributed to the intra-ligand charge transfer transitions, assigned to $\pi-\pi^{*}$ and $n-\pi^{*}$ transitions. In hybrid derivatives, the intra-ligand transitions were found to be slightly shifted in the region 241-364 $\mathrm{nm}$ as a result of coordination. Copper(II) derivative of TBAP displayed band in the region $574 \mathrm{~nm}$ due to ${ }^{2} \mathrm{~B}_{1} \mathrm{~g} \rightarrow{ }^{2} \mathrm{~A}_{1} \mathrm{~g}$ transition typical of square planar geometry ${ }^{16}$. Further confirmation of above geometry was done by magnetic moment value 1.92 BM. Absorption spectrum of nickel(II) complex displayed three d-d bands at $410 \mathrm{~nm}$, $602 \mathrm{~nm}$ and $727 \mathrm{~nm}$. These correspond to ${ }^{3} \mathrm{~A}_{2} \mathrm{~g}(\mathrm{~F}) \rightarrow{ }^{3} \mathrm{~T}_{1} \mathrm{~g}(\mathrm{P}),{ }^{3} \mathrm{~A}_{2} \mathrm{~g}(\mathrm{~F}) \rightarrow{ }^{3} \mathrm{~T}_{1} \mathrm{~g}(\mathrm{~F}),{ }^{3} \mathrm{~A}_{2} \mathrm{~g}(\mathrm{~F})$ $\rightarrow{ }^{3} \mathrm{~T}_{2} \mathrm{~g}(\mathrm{~F})$ transitions respectively, being typical of an octahedral geometry ${ }^{17}$. This geometry was further supported by its magnetic susceptibility value $(2.97 \mathrm{BM})$, where that of usual octahedral nickel(II) complexes are 2.9-3.3 $\mathrm{BM}^{18}$. Cobalt(II) complex displayed d-d bands in the region 427, 614 and $741 \mathrm{~nm}$, which were assigned to ${ }^{4} \mathrm{~T}_{1} \mathrm{~g}(\mathrm{~F}) \rightarrow{ }^{4} \mathrm{~T}_{1} \mathrm{~g}(\mathrm{P}),{ }^{4} \mathrm{~T}_{1} \mathrm{~g}(\mathrm{~F}) \rightarrow{ }^{4} \mathrm{~A}_{2} \mathrm{~g}(\mathrm{~F})$, ${ }^{4} \mathrm{~T}_{1} \mathrm{~g}(\mathrm{~F}) \rightarrow{ }^{4} \mathrm{~T}_{2} \mathrm{~g}(\mathrm{~F})$ transitions, respectively. These transitions correspond to the octahedral geometry of cobalt(II) complex ${ }^{17}$. This geometry of cobalt (II) complex was also supported by its magnetic susceptibility value (4.87 BM), where that of usual octahedral cobalt(II) complexes are 4.8-5.2 $\mathrm{BM}^{19}$. $\mathrm{Zn}$ (II) TBAP is diamagnetic and its geometry was most possibly similar to $\mathrm{Cu}(\mathrm{II}) \mathrm{TBAP}$ derivative. Thus tetrahedral geometry was proposed for this complex.

\section{EPR spectra}

The x-band EPR was spectra recorded in DMSO at liquid nitrogen temperature $(77 \mathrm{~K})$. The observed $g_{\|}$and $\mathrm{g}_{\perp}$ values for CuTBAP were 2.28 and 2.06 respectively. The trend of $g_{\|}>\mathrm{g}_{\perp}$ indicated the presence of unpaired electron in the $\mathrm{d}_{\mathrm{x}-\mathrm{y}}{ }^{2}$ orbital. This is in agreement with the electronic absorption spectroscopic assignments. Square-planar geometry is thus confirmed for the complex. Furthermore ${ }^{20}$, for covalent environment $g_{\|}<2.3$ and for ionic environment $g_{\|} \geq$ 2.3. The reported CuTBAP complex with $g_{\| 1}<2.3$, confirmed the covalent character of the $\mathrm{Cu}$ (II) ligand bond. The $\mathrm{G}$ factor, defined as $G=\left(g_{\|}-2.0023\right) /\left(\mathrm{g}_{\perp}-2.0023\right)$ greater than 4 , suggested that the exchange interaction between the copper centres is negligible. On the basis of above observations, tentative structures for the complexes were assigned in Figure 1b,c.

\section{Thermal analyses of copper and cobalt complexes of the Schiff base ligand TBAP}

The TG curve of the CuTBAP showed three decomposition stages at $155-215{ }^{\circ} \mathrm{C}, 215-420{ }^{\circ} \mathrm{C}$ and $420-615{ }^{\circ} \mathrm{C}$ corresponding to the loss of coordinated water molecule, loss of phenolic part of the ligand moiety and loss of remaining part of the ligand containing thiophene part with a mass loss of 5.53\% (calc. 5.56\%), 38.13\% (calc. $38.12 \%$ ) and $35.64 \%$ (calc. $35.67 \%$ ) respectively. CoTBAP showed four decomposition stages in the range $150-210{ }^{\circ} \mathrm{C}, 210-365{ }^{\circ} \mathrm{C}$, $365-560{ }^{\circ} \mathrm{C}$ and $560-725{ }^{\circ} \mathrm{C}$, with a weight loss of $4.59 \%$ (calculated $4.61 \%$ ), $18.18 \%$ (calculated 18.2\%), 36.66\% (calculated 36.65\%) and $21.25 \%$ (calculated $21.28 \%$ ) corresponding to the loss of, coordinated water molecule, chlorine, phenolic part of the ligand and loss of remaining part of the ligand moiety respectively. Above $615{ }^{\circ} \mathrm{C}$ and $725{ }^{\circ} \mathrm{C}$ a horizontal curve was observed due to the formation of metal oxide $(\mathrm{CuO}$ and $\mathrm{CoO}$ respectively) as the final residue (Figure 1d). 


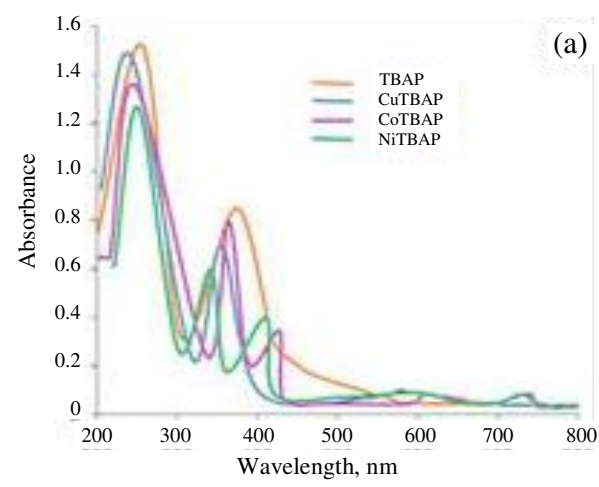

(a)

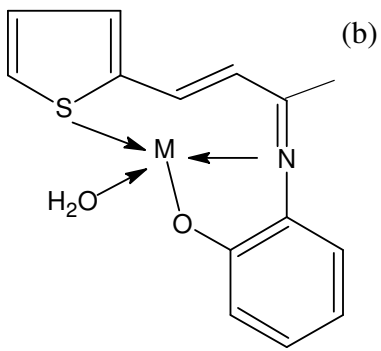

$\mathrm{M}=\mathrm{Cu}(\mathrm{II}), \mathrm{Zn}(\mathrm{II})$

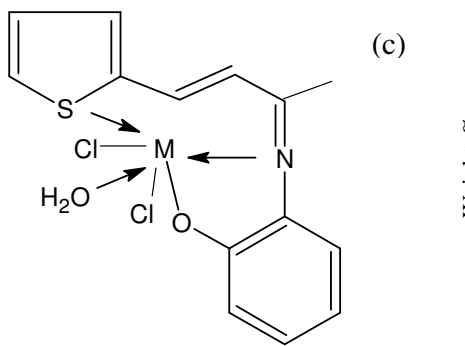

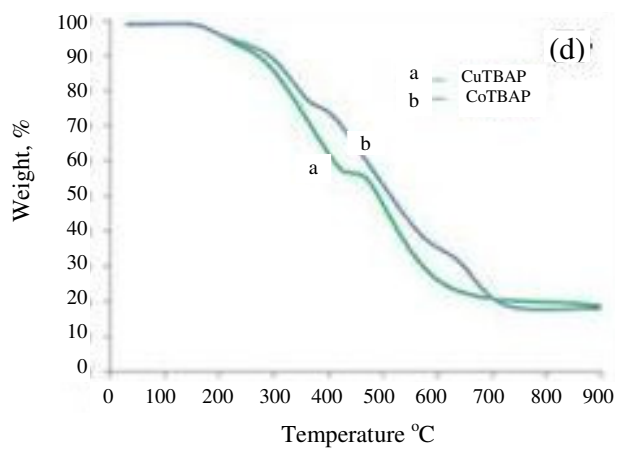

Figure 1. (a) UV of TBAP and its complexes, (b,c) Tentative structure of complexes and (d) TGA of copper and cobalt complexes of the Schiff base ligand TBAP

\section{Chemical nuclease activity}

Considerable interest is shown in the DNA cleavage reactions that are activated by transition metal complex ${ }^{21}$. Certain metal organic hybrids when interacted with DNA bring about the breakage of DNA strands as revealed by gel electrophoresis technique. Thus, in the case of cancer genes, after the cleavage of a DNA strand, the DNA double strands breaks. The replication ability of cancer gene is destroyed thereby. To gauge the DNA cleavage ability of TBAP and its transition metal organic hybrids by gel electrophoresis, CT DNA (30 $\mu \mathrm{M})$ was incubated with TBAP and its hybrid derivatives $(50 \mu \mathrm{M})$ in the presence of $\mathrm{H}_{2} \mathrm{O}_{2}$ $(40 \mu \mathrm{M})$ as an oxidant. $\mathrm{Cu}(\mathrm{II})$ and $\mathrm{Co}(\mathrm{II})$ derivatives of TBAP afforded complete DNA cleavage, while ZnTBAP showed partial cleavage and NiTBAP did not show any cleavage. Control experiments performed using DNA $+\mathrm{H}_{2} \mathrm{O}_{2}$ and DNA $+\mathrm{H}_{2} \mathrm{O}_{2}+$ TBAP on separate lanes revealed no cleavage of DNA even on longer exposure of time (Figure 2).

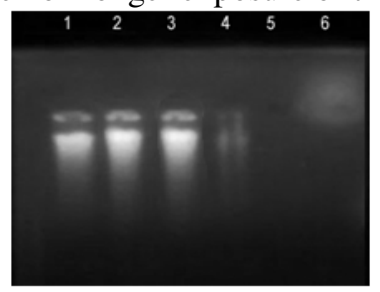

Figure 2. $\mathrm{H}_{2} \mathrm{O}_{2}$ induced CT DNA cleavage of TBAP and its complexes, Lane 1: DNA+ $\mathrm{H}_{2} \mathrm{O}_{2}$, Lane 2: DNA+ ligand $+\mathrm{H}_{2} \mathrm{O}_{2}$, Lane 3: DNA+ NiTBAP $+\mathrm{H}_{2} \mathrm{O}_{2}$, Lane 4: DNA+ ZnTBAP $+\mathrm{H}_{2} \mathrm{O}_{2}$, Lane 5: DNA+ CoTBAP $+\mathrm{H}_{2} \mathrm{O}_{2}$, Lane 6: DNA+ CuTBAP $+\mathrm{H}_{2} \mathrm{O}_{2}$ 
General oxidative mechanisms projected, report for DNA cleavage by hydroxyl radicals via. Abstraction of a hydrogen atom from sugar units and envisage the release of specific residues arising from transformed sugars, depending on the site from which the hydrogen atom is removed. The reaction is modulated by hybrid derivatives bound hydroxyl radical or a peroxo species generated from the co-reactant $\mathrm{H}_{2} \mathrm{O}_{2}$. The effectual cleavage efficiency of TBAP derivatives compared to that of the control is due to their proficient DNA binding ability.

\section{Antimicrobial activity}

In vitro antimicrobial activity (Table 1, Figure 3) against bacteria Escherichia coli (plate a), Pseudomonas aeruginosa (plate b), Klebsiella pneumonia (plate c), Staphylococcus aureus (plate d) and Staphylococcus saprophyticus (plate e) and fungi Candida albicans (plate f) was carried out with the synthesized compounds by Kirby-Bauer disc diffusion method. Mueller-Hinton agar and Sabouraud dextrose agar were used as medium for bacteria and Candida respectively. The activity was compared with standard antibacterial agent (Ciprofloxacin) and antifungal agent (Nystatin). The results tabulated in Table 1 suggest that the compounds exhibit good inhibitory effect against most of the tested microbes. From the antimicrobial activity data it was found that the zone of inhibition is much larger for metal organic hybrids than TBAP (Figure 3). A probable method of enhancing toxicity of complexes could be speculated by Overtone's concept and chelation theory.

Table 1. Antibacterial activity of TBAP and its metal complexes (mm)

\begin{tabular}{ccccccc}
\hline \multirow{2}{*}{ Compounds } & \multicolumn{3}{c}{ Gram (-ve) bacteria } & \multicolumn{2}{c}{ Gram (+ve) bacteria } & Fungi \\
\cline { 2 - 7 } & E. coli & $\begin{array}{c}P . \\
\text { aeruginosa }\end{array}$ & $\begin{array}{c}\text { Kneumonia } \\
\text { pneureus }\end{array}$ & $\begin{array}{c}\text { S. } \\
\text { saprophyticus }\end{array}$ & $\begin{array}{c}C . \\
\text { albicans }\end{array}$ \\
\hline TBAP & 10.0 & - & - & 9.0 & 10.0 & - \\
CuTBAP & 23.0 & 19.0 & 21.0 & 23.0 & 20.0 & 15.0 \\
CoTBAP & 17.0 & 15.0 & 18.0 & 19.0 & 23.0 & 15.0 \\
NiTBAP & 12.0 & 13.0 & 13.0 & 12.0 & 17.0 & - \\
ZnTBAP & 16.0 & 16.0 & 17.0 & 15.0 & 15.0 & - \\
Ciprofloxacin & 25 & 23 & 23 & 26 & 24 & \\
Nystatin & & & & & & 26 \\
\hline
\end{tabular}

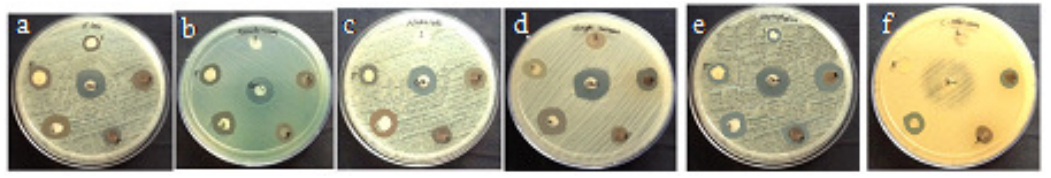

Figure 3. Antimicrobial activity of TBAP and its hybrid derivatives

CuTBAP displayed greater antimicrobial activity than other hybrid derivatives of TBAP. The difference in the enormity of antimicrobial activities of metal hybrids comes from various factors such as, nature of the counter ions that neutralize the complex, solubility, nature of metal ions, charge and geometrical structure of the complexes ${ }^{22}$.

\section{Conclusion}

In this report, coordination chemistry of the Schiff base ligand TBAP, obtained from the reaction of 4-(thiophen-2-yl)but-3-en-2-one with 2-aminophenol, had been described. $\mathrm{Cu}(\mathrm{II}), \mathrm{Ni}(\mathrm{II}), \mathrm{Co}(\mathrm{II})$ and $\mathrm{Zn}(\mathrm{II})$ complexes of TBAP were synthesized and characterized by spectral and analytical data. Based on these data, square-planar geometry was assigned to CuTBAP, octahedral geometry for CoTBAP and NiTBAP and a tetrahedral geometry for 
ZnTBAP. Metal complexes showed higher antimicrobial activity than TBAP. Interaction of the complexes with CT-DNA was investigated by gel electrophoresis in the presence of $\mathrm{H}_{2} \mathrm{O}_{2}$. Cu, Co and $\mathrm{Zn}$ complexes of TBAP were found to cleave DNA effectively. As these complexes were found to cleave the DNA, it can be concluded that the compounds would hamper the growth of the pathogenic organism by cleaving the genome.

\section{References}

1. Sharma A K and Chandra S, Spectrochim Acta Part A, 2013, 103(15), 96-100; DOI:10.1016/j.saa.2012.11.012

2. Abdelhamid A O, J Heterocycl Chem., 2009, 46(4), 680-686; DOI:10.1002/jhet.141

3. Wu X M, Wu X S and Xu J Y, J Chin Pharm Univers., 1996, 27(1), 641-646.

4. Burnett A D, Caplen A M, Davis R H and Clader J, J Med Chem, 1994, 37(12), 1733-1736; DOI:10.1021/jm00038a001

5. Robson R, Inorg Nucl Chem Lett., 1970, 6(2), 125-128; DOI:10.1016/00201650(70)80324-5

6. Pfaller M A, Burmeister L and Rinaldi M G, J Clin Microbiol., 1988, 26(8), 1437-1441.

7. Abdlseed F A and El-ajaily M M, Int J Pharma Tech Res., 2009, 1(4),1097-1103.

8. Shrivastava V, Shrivastava S K and Mishra A P, J Indian Chem Soc., 1995, 22, 434.

9. Refat M S, El-Deen I M, Anwar Z M and El-Ghol S, J Mol Stru., 2009, 920(1-3), 149-162; DOI:10.1016/j.molstruc.2008.10.059

10. Abdel-Latif S A, Hassib H B and Issa Y M, Spectrochim Acta A, 2007, 67(3-4), 950957; DOI:10.1016/j.saa.2006.09.013

11. Maurya R C and Patel P, Spectrosc Lett., 1999, 32(2), 213-236;

DOI:10.1080/00387019909349979

12. Singh B K, Jetley U K, Sharma R K and Bhagwan S G, Spectrochim Acta A, 2007, 68(1), 63-73; DOI:10.1016/j.saa.2006.11.001

13. Ferraro J R, Low Frequency Vibrations of Inorganic and Coordination Compounds, $1^{\text {st }}$ Ed., Plenum Press, New York, 1971, 168-196.

14. Sheela C D, Anitha C, Tharmaraj P and Kodimunthri D, J Coord Chem., 2010, 63(5), 884-893; DOI:10.1080/00958971003660416

15. Arish D and Sivasankaran Nair M, J Mol Struct., 2010, 983(1-3),112-121; DOI:10.1016/j.molstruc.2010.08.040

16. Al-Shaalan N H, Molecules, 2011, 16(10), 8629-8645;

DOI:10.3390/molecules16108629

17. Alaghaz A M A and Ammar R A, EurJ Med Chem., 2010, 45(4), 1314-1322;

DOI:10.1016/j.ejmech.2009.12.008

18. Chandra S and Gupta K, Transit Metal Chem., 2002, 27(2), 196-199.

19. Alaghaz A M A, Ammar R A A and El-Sayed B A, J Mol Struct., 2013, 1035, 83-93; DOI:10.1016/j.molstruc.2012.09.032

20. Kivelson D and Neiman R, J Chem Phys., 1961, 35, 149; DOI:10.1063/1.1731880

21. Hertzberg R P and Dervan P B, J Am Chem Soc., 1982, 104(1), 313-315; DOI:10.1021/ja00365a069

22. Singh S C J, Gupta N and Singh R V, Indian J Chem., 1995, 34(9), 733-736. 